\title{
Limitations of the implementation of the concept of sustainable development in a coal mining region (the case of the Kemerovo region - Kuzbass)
}

\author{
Olga Zonova ${ }^{1 *}$, Natalia Kudrevatykh ${ }^{1}$, Oksana Sheveleva $^{1}$, Ekaterina Slesarenko ${ }^{1}$, and \\ Nina Vagina ${ }^{1}$ \\ ${ }^{1}$ T.F. Gorbachev Kuzbass State Technical University, Department of Finance and Credit, 650000 \\ Kemerovo, 28 Vesennya st., Russian Federation
}

\begin{abstract}
A three-pronged approach to sustainable development of coalmining regions, which involves the combination of social stability, economic efficiency and environmental sustainability, is discussed in the article. The factors that restrain the increase in the social well-being of the population and the reduction of the environmental burden are identified in the context of the presented limitations on the implementation of the concept of sustainable development of coal mining territories.
\end{abstract}

The concept of sustainable development emerged as a result of public awareness of the need to solve global environmental problems that had an adverse impact on the further socio-economic development of both individual territorial entities and countries as a whole. [1-5].

Since the 1980 s the scientific community began to pay more and more attention to this problem. However, the analysis of existing approaches to the interpretation of the sustainable development concept allows considering them as almost identical.

In most cases, sustainable development is understood as such development that meets the current needs of society, but does not jeopardize the ability of future generations to meet their own needs. That is, sustainable development is development within the limits of the permissible ("sparing") anthropogenic impact on the biosphere. A quantitative assessment of the permissible limit of anthropogenic impact on the environment is becoming a very urgent problem, but difficult to solve due to the lack of the necessary mehods.

The component analysis of the "sustainable development" category reveals two imperatives:

1) the need to meet social needs;

2) restrictions on the exploitation of natural resources and the ability of the ecosystem to recover after anthropogenic impact.

\footnotetext{
* Corresponding author: zov.fk@kuzstu.ru
} 
The authors consider this approach to the definition very contradictory, since nonrenewable resources are not reproduced. Any withdrawal of non-renewable resources already limits the ability of future generations to meet growing needs.

Besides, when referring to the essence of the concepts of "sustainability" and "development", it is also possible to reveal certain contradictions. So, a number of researchers note that the last two terms are mutually exclusive, since development is a quantitative and qualitative transformation of a complex system that characterizes the forward movement, and therefore, what kind of sustainability can we talk about. Other researchers, on the contrary, argue that "sustainability does not imply a lack of growth," but the quality of economic growth remains an important issue.

We reserve the right to reconcile the warring parties and consider development in the context of sustainability as a special case of movement that characterizes a trajectory of socio-economic progress in which the industrial develops on a scale that does not threaten the security of all mankind.

We believe that the time has come for a change in views on the role of the state in addressing sustainable development issues. Politics should stop being conservative and declarative. In our opinion, it is advisable to switch to an adaptive-preventive policy when ensuring sustainable development, which presupposes the development of preventive measures in advance.

Almost 30 years have passed since the adoption of the Concept of Sustainable Development at the conference in Rio de Janeiro. During this time, of course, there have been positive changes, but a large number of problems remain:

- an increase in the already high natural capital intensity of commodities;

- extremely low rates of technological renewal of production;

- extensive use of natural resources;

- low quality of investments in fixed assets (mainly in the mining sector for the purchase of machinery and equipment), which does not lead to structural changes in the regional economy;

- an insignificant share of innovative products in the total volume of manufactured products.

The state should create conditions for the development and diffusion of technologies through the implementation of industrial, environmental, investment and innovation policies. State support, on the one hand, will contribute to technological development and renovation of production facilities, and on the other, generate demand for environmentally friendly technologies. Determination of strategic objectives within the framework of sustainable development for short, medium and long terms will allow business entities to develop and implement investment projects to introduce environmentally friendly and resource-saving technologies.

World experience in this field shows that the most efficient tools for tackling these strategic tasks are fiscal measures: regressive tax rates when introducing environmentally friendly technologies, and vice versa, increasing coefficients for environmental payments when using "dirty" technologies.

The authors also believe that a number of environmental problems can be solved by the use of mechanisms of public-private partnership and increasing corporate social responsibility of businesses, since any company generate a socio-economic and environmental burden in its footprint area, thereby accelerating or slowing down its development. Therefore, corporate social responsibility is a special case of the implementation of the principles of sustainable development at the micro level.

The current situation can be considered paradoxical due to the fact that large business began to show social activities quite a long time ago, and the regulatory framework governing these activities began to form relatively recently. So, 17 goals of sustainable 
development are formulated in the Resolution of the UN General Assembly. However, not all enterprises are guided by these goals in their activities. A similar practice occurs in the Kemerovo Region - Kuzbass, but its scale is insignificant and, often, not within the framework of the goals of the Concept of Sustainable Development.

Perhaps the main obstacle is the contradiction between making profit as the main goal of any commercial activity and strategic objectives in the framework of sustainable development. In this connection, the need to introduce environmentally friendly technologies is considered by business owners as additional costs, while in the interests of stakeholders, they focus on increasing the value of the business by improving the organization's business reputation in the market.

A number of studies reflect a direct relationship between the business reputation of companies and their social and environmental activities in their footprint areas. That is why the format of sustainable development goals must be changed from declarative calls for economic interest to strict "rules of the game" for businesses.

A limitation of the implementation of the concept of sustainable development is the voluntary use of ISO 26000:2010 "Social responsibility"; ISO 14001:2015 "Environmental Management Systems. Requirements and Application Guidance "

Obviously, environmental problems cannot be considered outside the socio-economic context, since sustainable development implies social equality, economic efficiency and environmental sustainability [6].

We believe it is necessary to expand the three-pronged approach, since further sustainable development should be based on breakthrough innovations. In this connection, one of the main factors of sustainable development is the technical and technological component, which is closely related to the investment and innovation component. These factors should become the drivers of economic growth in the Kemerovo Region - Kuzbass.

The limitations of the implementation of the concept of sustainable development and the conditions that restrain technical and technological, investment and innovation development in Kuzbass are:

- high technological inertia of coal industry enterprises;

- significant level of depreciation of fixed assets;

- low share of investments in fixed assets of environmental protection in the total volume of investments in the mining industry;

- insignificant indicators of innovation of coal industry enterprises;

- dependence of capital goods on imports;

- disengagement of the state from the processes of resource rent redistribution;

- often low environmental responsibility of the coal business owners.

The authors are accepting of the fact that the global challenges of our time have primarily affected the coal industry [7-9]. The decrease in coal consumption in the world due to the transition of individual countries to low-carbon development strategies and the increase in the share of renewable energy sources in the energy balances of developed and developing countries pushes towards the best solution for humanity to the dilemma: economic growth and/or a favorable environment. In addition, at present, humanity's demand for environmental friendliness of production, including in the coal industry, is high.

The coal industry is one of the main entities causing colossal damage to the environment, which is recognized not only by Russian scientists, but also by their foreign colleagues [10-15]. An increase in coal production leads to an increase in the areas of disturbed lands, and the share of reclaimed lands in the total volume of disturbed lands is extremely small (Table 1) 
Table 1. Indicators characterizing the anthropogenic load on the environment of the Kemerovo region - Kuzbass.

\begin{tabular}{|l|c|c|c|}
\hline Indicators & 2017 & 2018 & 2019 \\
\hline Coal production, million tons & 241.4 & 255.8 & 249.4 \\
\hline Area of disturbed lands, thousand hectares & 83.5 & 88.2 & 91.7 \\
\hline Reclaimed land area, hectares & 227 & 107 & - \\
\hline $\begin{array}{l}\text { Emissions of pollutants into the atmosphere, } \\
\text { thousand tons }\end{array}$ & 1488 & 1384 & 1760 \\
\hline Air pollutants caught and neutralized, thousand tons & 4422 & 3674 & 3380 \\
\hline Water intake, million cubic meters & 1996 & 1849 & 1831 \\
\hline $\begin{array}{l}\text { Discharge of wastewater containing pollutants, } \\
\text { million cubic meters }\end{array}$ & 433 & 355 & 303 \\
\hline $\begin{array}{l}\text { Production and consumption waste generated, } \\
\text { million tons }\end{array}$ & 3147 & 3603 & 3790 \\
\hline $\begin{array}{l}\text { Use and disposal of production and consumption } \\
\text { waste, million tons }\end{array}$ & 1667 & 1012 & 1905 \\
\hline
\end{tabular}

According to official statistics, over the past three years (2017-2019), emissions of pollutants into the atmosphere have increased: according to experts, $86 \%$ of harmful emissions are mine methane. Positive dynamics can be traced in relation to the discharge of wastewater containing pollutants, nevertheless, $97 \%$ of the discharged water is mine and open pit waters.

Depressing is the fact that the share of wastewater discharged without treatment is about $70 \%$. The situation is aggravated by the fact that coal mining is accompanied by destruction and displacement of rocks resulting in the generation of production waste. Unused overburden and enclosing rocks are stored in dumps, which are dangerous due to emission of pollutants, erosion and spontaneous combustion. In addition, dumps cause the withdrawal of a significant amount of scarce land, pollution of groundwater, soil and air. In case of underground mining, the situation is also ambiguous: the proportion of operating working faces with full and/or partial backfilling of the worked-out space is extremely low.

Undoubtedly, there are positive shifts in terms of waste generation and disposal, but the situation is far from ideal, and the negative impact on the environment continues. This is manifested in the form of degradation of natural landscapes, pollution of air and water bodies, withdrawal of land for storage of industrial waste, etc. All these negative aspects, in turn, have an unfavorable effect on the life expectancy of the population of coal-mining regions, the growth of congenital anomalies and the human morbidity rate, and therefore there is no doubt about the need for further research in the field of anthropogenic impact on the environment and sustainable development of coal industry territories.

We believe that the implementation of the sustainable development concept in the Kemerovo region - Kuzbass requires technological modernization of primary sectors of the economy, as well as the establishment and development of manufacturing industries that create a product with high added value.

In addition, to achieve sustainable development goals:

- the production and economic activities of coal mining enterprises should be based not on the maximum possible extensive use of the natural resource potential of the environment through the operation of an outdated facilities, but on the rational consumption of natural resources through the use of innovative progressive resource-saving technologies;

- making management decisions related to anthropogenic activities should be accompanied by an analysis of possible environmental consequences; 
- an increase in the standard of living of the population should be considered both through a socio-economic prism and on the basis of improving the environment by reducing the anthropogenic impact on it.

Investing in environmentally friendly technologies leads to a change in the technoeconomic paradigm, which may result in the reduction of the natural capital intensity of commodities and the minimization of the costs of eliminating the negative impact on the environment, and this is the interests of the current and future generations.

\section{References}

1. T. Absalyamov, S. Absalyamova, Ch. Mukhametgalieva, R. Sakhapov, J. of Ph. Con. Ser., 1730(1) 012109 (2021)

2. H.A. Alkanaani J of Eng. and Appl. Sci., 14(18), 6858-6865 (2019)

3. E.-E. Halmaghi, M.-M. Neag Land Forc. Ac. Rev., 24(1):45, 53 (2019)

4. C. Joseph Soc. Res. J., 9(3) (2013)

5. P.K. Mishra, Managing Sustainable Development: Concepts, Issues \& Challenges (AgriTech Publishing, New Delhi, India, 2019)

6. E. Slesarenko, O. Sheveleva, N. Kudrevatykh, N. Vagina, E3S Web of Conf., 174, 04002 (2020)

7. J. Ritterbusch, K. Severing, P. Henheik, A. Tröger Glob. Challen., 2(1):1870003 (2018)

8. I. Schröder, Ed de Jonge, E. Mooij, F. Evers Conf: CARPE Conference 2019, 10564 (2019)

9. G. Borici ILIRIA Inter. Rev., 6(2) (2017)

10. L. Sagdeeva, L. Starikova, I. Trapeznikova E3S Web of Conf., 105:04008 (2019)

11. X. Chen, X. Shi Env. Devel. and Sust., 23(2) (2021)

12. W. Li, D. Wang, H. Li IOP Conf. Ser. Earth and Envir. Sci., 237(2):022039 (2019)

13. G. Anfu, Ch. Tan, H. Zhao Sustain., 11(16):4366 (2019)

14. P. Trechera Ruiz, T. Moreno, P. Córdoba and oth. Inter. J. of Coal Geol., 235:103677 (2021)

15. N. Ianc, C. Boantă, I. Gherghe, C. Tomescu MATEC Web of Conf., 305:00030 (2020) 